\title{
Effect of Two Months Naturopathy Treatment in Non Insulin Dependent Diabetes Mellitus Patients
}

\author{
Rukamani Nair ${ }^{1}$, Deepali Saxena ${ }^{2}$, Ranjna Chawla ${ }^{3}$, V. R. Sood ${ }^{4}$, Akhil Jain ${ }^{5}$ \\ ${ }^{1}$ Medical Superintendent, Bapu Nature Cure Hospital \& Yogashram, Mayur Vihar-I, Delhi-91, India \\ ${ }^{2}$ Senior Research Fellow, Bapu Nature Cure Hospital \& Yogashram, Mayur Vihar-I, Delhi-91, India \\ ${ }^{3}$ Scientist C, GIPMER, New Delhi, India \\ ${ }^{4}$ Physician, Mayur Vihar Phase-2 clinic, Mayur Vihar-II, Delhi-91, India \\ ${ }^{5}$ Biostatistician, Bapu Nature Cure Hospital \& Yogashram, Mayur Vihar-I, Delhi-91, India
}

\begin{abstract}
Type 2diabetes is emerging as a serious medical and socioeconomic problem world over. The number of people with type 2diabetes mellitus are increasing due to population growth, ageing, and urbanization and increasing prevalence of obesity and physical inactivity. The aim of the study is to evaluate the effect of Naturopathy on the Fasting blood glucose (FBG), postprandial blood glucose (PPBG) levels and Body Mass Index (BMI) in patients with Type 2 Diabetes Mellitus. A total of 50 patients were recruited and divided into two Groups. Group I (Intervention group = 32 sittings) were on both naturopathy and allopathic medication with diet control and Group II (control group) were on allopathic medication and diet control. The study parameters were assessed at baseline and after two months intervention. The result suggested significant changes in the levels of FBG and PPBG in both the groups and improvement was seen in Body Mass Index (BMI) only in group 1 patients.
\end{abstract}

Keywords: Type 2 Diabetes mellitus, Naturopathy, Fasting blood glucose (FBG), Postprandial blood glucose (PPBG), Body Mass Index (BMI)

\section{Introduction}

Diabetes mellitus type 2 (formerly non insulin-dependent diabetes mellitus (NIDDM) or adult-onset diabetes) is a metabolic disorder resulting because of genetic and environmental factors and is characterized by impaired $\beta$ cell function and insulin action ${ }^{[1]}$. As the disease progresses tissue or vascular damage ensues leading to severe diabetic complications such as coronary artery disease, renal failure, nervous disorder and also blindness ${ }^{[2]}$.

Diabetes is fast becoming the epidemic of $21^{\text {st }}$ century. According to latest World Health Organization (WHO) report India has 31.7 million diabetic patients, and the number is expected to increase to 79.4 million by $2030^{[3]}$.

It has been reported that diabetes is mostly due to the environmental and hereditary causes which lead to high level of glucose in the blood called hyperglycemia ${ }^{[4]}$. The growing incidence of diabetes is mainly attributable to the increasing rates of urbanization, migration from rural to urban areas and adoption of sedentary life style and unhealthy diet habits ${ }^{[5],[6] .}$ Type 2 diabetes mellitus occurs as a result of progressive insulin secretory defect along with insulin resistance ${ }^{[7-9]}$. Its different forms are characterized by a variable degree of insulin resistance and $\beta$ cells dysfunction [10].

Treatment of type 2 diabetes mellitus through Naturopathy modalities like hydrotherapy, mud therapy, massage therapy, diet therapy is aimed to improve circulation to the cells with increased activation of venous and lymphatic system. These modalities work by increasing contraction and then relaxation of muscles and blood vessels to provide sufficient blood supply along with nutrients and oxygen, required for normal vital activity of the cells. The venous circulation and lymphatic system are very important in the process of elimination of waste products from the body. Increased activation of these eliminatory channels through nature cure modalities enhances the transport of waste materials to the heart and then eliminative sites of the body like kidney and skin. This process of increased recycling may therefore promote re-establishing homeostasis resulting in the normal integrity and functioning of the cells and organs with increased synthesis of insulin receptors and reduced insulinreceptor blunting. This enhanced homeostatic condition may further lead to increase sensitivity of the cells to respond to normal insulin action (increased insulin sensitivity) with glycemic control (increased glucose tolerance). Besides reestablishing homeostasis, this system of nature cure medicine, at the same time, may strengthen even other body organs to perform their normal functioning in a better manner ${ }^{[11]}$.

\section{Materials and Methods}

Present study was conducted at Science, Research and Innovation Department of Bapu Nature Cure Hospital and Yogashram in collaboration with department of Biochemistry, GIPMER. Patients were recruited through advertisements (wall posters, newspaper, banners), and organizing camps in nearby localities of the Hospital. All patients were in the age range of 30- 60 years. Adequate counseling was carried out for the disease awareness as well as about the study trial. Eligible patients were recruited after taking consent according to the inclusion and exclusion criteria as per American Diabetes Association guidelines.

\section{Volume 5 Issue 1, January 2016}




\section{International Journal of Science and Research (IJSR) \\ ISSN (Online): 2319-7064}

Index Copernicus Value (2013): 6.14 | Impact Factor (2014): 5.611

\section{Study population}

A total of 50 proven type 2 diabetes patients (including 20\% dropouts) were enrolled and randomized in two groups. Randomization was done by picking up a chit randomly from a box containing equal chits of both the groups. Group 1 (Intervention group) included 25 patients taking naturopathy and allopathic medication, Group 2 (Control group) included 25 patients taking only allopathic medication. Before starting the trial, intensive counselling was done to educate them about the disease, and its risk factors, the benefits of the treatment ( Naturopathy, diet control and drugs), number of treatment visits to the Hospital and about the parameters to be investigated during the study period. After their awareness and counselling about the disease, Naturopathic modalities were administered to patients.

\section{Study design}

This was a simple randomized study in which Naturopathy treatments were provided to the intervention group five times in a week for first month and thrice in a week for second month. The total number of visits by a patient in 2 months intervention was 32 . The therapies were given in the morning or in the evening on empty stomach or $3 \mathrm{hrs}$ after meal. Diet chart was provided to both the groups and patients were advised to follow it strictly which was monitored by maintaining a diary. The dose of Medication to the patients of both the groups was monitored by the concerned doctor. The study parameters i.e. Symptoms score (B. P, weight, height, BMI, W/h ratio) and glycemic status such as blood glucose (fasting and PP2BS) were assessed at baseline and after completion of 2 months treatment. During the treatment, patients were instructed strictly to continue oral hypoglycemic drug.

\section{Treatment}

Duration of Naturopathy treatment was for 60 minutes. Following were the treatments:

\section{Naturopathic treatment \\ a) Massage:}

Oil was smeared on the abdomen and spine to the interventional group which enhances not only blood circulation but also tones up the muscles while improving structural and functional status and hence insulin sensitivity. It also helps in mobilizing fat and thus reducing the weight. All the movements of massage like Stroking, Friction, Kneading, Percussion and Vibration were for a period of 20 minutes making muscles and fat tissues more functional and sensitive ${ }^{[12] \text {. }}$

\section{b) Cold Hip bath:}

The Cold hip bath $\left(32^{\circ} \mathrm{C}\right.$ to $\left.36^{\circ} \mathrm{C}\right)$ of 20 minutes was given to the patients for 20 minutes which produces profound effect upon all bodily functions especially of the abdomen. Due to contraction of cutaneous blood vessels, there was increased visceral circulation to abdomen also, heightens nutritive process in the parts concerned. It excites contraction of the muscular structures of visceral and thus helps to stimulate the functions of abdominal and pelvic organs including pancreas, liver, bladder etc. and structures involved with act of defecation.

\section{c) Mud pack:}

Mud pack was applied to the patients of interventional group for 20 minutes especially over the abdominal region at empty

stomach by the use of clay pack which is free from contamination. This therapy helps to improve blood circulation to the abdominal and pelvic regions, therefore enhancing functional capacity as well as helps to remove toxins by diluting and absorbing the toxic substances of the body ${ }^{[13]}$.

\section{Allopathic Medicines}

Allopathic treatments were used in conjunction with naturopathy treatments. The prescribed disease modifying drugs by allopathic physician were Metformin, Glimiperide, glibenclamide and Pioglitazone. The doses were kept stable and the participants were asked to consult at the end of every month to review the medication.

\section{Results}

Significant improvement was observed in glycemic status (blood glucose fasting and PP) in both the groups after two months treatment. (Table 1, Table 2). Also significant improvement was seen in body mass index (BMI) only in group 1 patients taking combined therapy of naturopathy and allopathic medicines $(\mathrm{P}<0.01)$ as compared to control group patients taking only allopathic medicines (Table 3 ). The results suggested significant role of naturopathy in controlling type II diabetes.

Table 1: Effect of naturopathy treatment on fasting blood glucose levels before and after 2 months

\begin{tabular}{|c|c|c|c|}
\hline & $\begin{array}{c}\text { Fasting glucose } \\
\text { (mg/dl), before } \\
\text { treatment } \\
(\text { MEAN } \pm \text { SD) }\end{array}$ & $\begin{array}{c}\text { Fasting glucose } \\
\text { (mg/dl) after 2 } \\
\text { Months treatment } \\
\text { (MEAN } \pm \text { SD) }\end{array}$ & P- value \\
\hline $\begin{array}{c}\text { Group-1 } \\
\text { (Treatment group) }\end{array}$ & $151.6 \pm 61.0$ & $126.1 \pm 37.1^{*}$ & 0.015 \\
\hline $\begin{array}{c}\text { Group-2 } \\
\text { (Control group) }\end{array}$ & $144.7 \pm 70.5$ & $123.6 \pm 42.0$ & 0.029 \\
\hline$*_{p}<0.05, * * p<0.01, * * * p<0.001$
\end{tabular}

Table 2: Effect of naturopathy treatment on PP blood glucose levels before and after 2 months treatment

\begin{tabular}{|c|c|c|c|}
\hline & $\begin{array}{c}\text { PP glucose } \\
\text { (mg/dl) before } \\
\text { treatment } \\
\text { (MEAN } \pm \text { SD) }\end{array}$ & $\begin{array}{c}\text { PP glucose }(\mathrm{mg} / \mathrm{dl}) \\
\text { after 2 Months } \\
\text { treatment } \\
\text { (MEAN } \pm \text { SD) }\end{array}$ & $\begin{array}{c}\text { P- } \\
\text { value }\end{array}$ \\
\hline $\begin{array}{c}\text { Group-1 } \\
\text { (Treatment group) }\end{array}$ & $252.0 \pm 90.1$ & $191.7 \pm 68.7 * * *$ & 0.000 \\
\hline $\begin{array}{c}\text { Group-2 } \\
\text { (Control group) }\end{array}$ & $247.7 \pm 67.7$ & $190.6 \pm 55.9^{* * *}$ & 0.000 \\
\hline$* p<0.05, * * p<0.01, * * * p<0.001$
\end{tabular}

Table 3: Effect of naturopathy treatment on BMI values before and after 2 months treatment

\begin{tabular}{|c|c|c|c|}
\hline & $\begin{array}{c}\text { BMI before } \\
\text { treatment } \\
(\text { MEAN } \pm \text { SD) }\end{array}$ & $\begin{array}{c}\text { BMI after 2 } \\
\text { Months treatment } \\
(\text { MEAN } \pm \text { SD) }\end{array}$ & $\begin{array}{c}\text { P- } \\
\text { value }\end{array}$ \\
\hline $\begin{array}{c}\text { Group-1 } \\
\text { (Treatment group) }\end{array}$ & $29.3 \pm 4.3$ & $28.9 \pm 4.3^{* *}$ & 0.009 \\
\hline $\begin{array}{c}\text { Group-2 } \\
\text { (Control group) }\end{array}$ & $27.6 \pm 5.8$ & $27.7 \pm 5.8$ & 0.606 \\
\hline
\end{tabular}

$* p<0.05, * * p<0.01, * * * p<0.001$

\section{Discussion}

\section{Volume 5 Issue 1, January 2016




\section{International Journal of Science and Research (IJSR)

Several Studies have shown that people who use complementary and alternative medicine (CAM) also have increased control over health and an overall orientation towards a healthy lifestyle ${ }^{[14],[15]}$. Previous studies have shown that the Naturopathic care to people with type 2 diabetes mellitus significantly improved glycemic control, increased physical activity, improved mood and reduced problem areas in diabetes ${ }^{[16]}$. Another study demonstrated the modifications in risk-factors that occur with long-term naturopathic care for T2DM with notable percentages of patients achieving improvements in glucose levels as measured by $\mathrm{HbAl}$ c and blood pressure measures ${ }^{[17] \text {. }}$

The present study proves that combined therapy of naturopathy and allopathy with diet control has a tremendous effect on improving body mass index. A significant reduction in the Body Weight and BMI was recorded in the interventional group. Body Mass Index provides a simple numeric measure of a person's "fatness" or "thinness", allowing health professionals to discuss over- and underweight problems more objectively with their patients ${ }^{[18]}$. Excessive body weight is associated with various diseases, particularly cardiovascular diseases, Type-2 Diabetes mellitus, Obstructive sleep apnea, certain types of cancer, and osteoarthritis. As a result, obesity has been found to reduce life expectancy ${ }^{[19]}$.

It is reported that Naturopathy modalities like hydrotherapy, mud therapy, massage therapy, diet therapy have a major therapeutic modality in the treatment of type 2 diabetes and regular practice of naturopathy modalities is effective in controlling of type 2 diabetes.

Naturopathy is not only feasible and safe but is compatible with other treatment systems in offsetting chronic diabetic conditions like hyperglycemia, hyperinsulinemia and insulin resistance. In addition to having great health promotive, disease preventive and restorative potential, it also act as a system of building body in harmony with constructive principles of Nature.

\section{Conclusion}

The study is novel and unique in nature. All participants assigned to naturopathy expressed high satisfaction as they found good change in status of their type 2 diabetes. Also these therapies together have potential to enhance the beneficial effects of standard medical management of diabetes mellitus type 2 and can be used as an effective integrative medicine. The important conclusion that can be drawn from this study is the need for well-designed large randomized clinical trials to assess the effectiveness of naturopathy on diabetes type II.

\section{Acknowledgement}

The author would like to thank Ministry of Ayush, Govt. of India for funding the research project and Dr. R. M. Nair Director, Bapu Nature Cure Hospital \& Yogashram, Mayur Vihar-1, New Delhi for providing the research facilities.

\section{References}

[1] P. Zimmet, K. G. M. M. Alberti, and J. Shaw, "Global and societal implications of the diabetes epidemic," Nature, vol. 414, no. 6865, pp. 782-787, 2001.

[2] M. S. Akhtar, N. Irshad, A. Malik, and Y. Kamal, "Need for new hypoglycemic agents: An overview," Int. J. Pharm. Sci. Res., vol. 4, pp. 77-82, 2013.

[3] S. Wild, G. Roglic, A. Green, R. Sicree, and H. King, "Global Prevalence of Diabetes: Estimates for the year 2000 and projections for 2030," Diabetes Care, vol. 27, no. 5, pp. 1047-1053, 2004.

[4] Tierney LM, McPhee SJ, Papadakis MA, "Current medical Diagnosis \& Treatment". International edition. New York: Lange Medical Books/McGraw-Hill. pp. 1203-1215, 2002.

[5] A. Ramachandran, R. C. Wan Ma, and C. Snehalatha, "Diabetes in Asia," Lancet, vol. 375, no. 9712, pp. 408418, 2010.

[6] a Ramachandran, R. Ambady, C. Snehalatha, a Samith Shetty, and a Nanditha, "Primary prevention of Type 2 diabetes in South Asians--challenges and the way forward.," Diabet. Med., vol. 30, no. 1, pp. 26-34, 2013.

[7] C. Turner, R. R. R. Holman, D. Matthews, T. D. R. D. R. Hockaday, J. Peto, R. C. C. Turner, R. R. R. Holman, D. Matthews, T. D. R. D. R. Hockaday, and J. Peto, "Insulin deficiency and insulin resistance interaction in diabetes: Estimation of their relative contribution by feedback analysis from basal plasma insulin and glucose concentrations," Metabolism, vol. 28, no. 11, pp. 10861096, 2014.

[8] J. M. Olefsky, O. G. Kolterman, and J. A. Scarlett, "Insulin action and resistance in obesity and noninsulindependent type II diabetes mellitus.," Am. J. Physiol., vol. 243, no. 1, pp. E15-30, 1982.

[9] I. Classification, "Standards of medical care in diabetes-2009.," Diabetes Care, vol. 32 Suppl 1, pp. S13-61, 2009.

[10] American Diabetes Association (ADA), "Report of the Expert Committee on the diagnosis and classification of diabetes mellitus," Diabetes Care, vol. 24, pp. S5-20, 2001.

[11] Naturopathic treatment for common ailments, 2005th ed. Central council of naturopathy and yoga, p. 38 , 2005.

[12] J.H. Kellogg, Art of Massage. University of Michigan Library, 1895.

[13] Important therapeutic modalities used in Naturopathy, 2006th ed. Central council of naturopathy and yoga, p. 1,5,47, 2006.

[14] R. L. Nahin, J. M. Dahlhamer, B. L. Taylor, P. M. Barnes, B. J. Stussman, C. M. Simile, M. R. Blackman, M. A. Chesney, M. Jackson, H. Miller, and K. K. McFann, "Health behaviors and risk factors in those who use complementary and alternative medicine.," BMC Public Health, vol. 7, no. 1, p. 217, 2007.

[15] M. Sasagawa, M. R. Martzen, W. J. Kelleher, and C. A. Wenner, "Positive correlation between the use of complementary and alternative medicine and internal health locus of control.," Explore (NY)., vol. 4, no. 1, pp. $38-41,2008$

[16]R. Bradley, K. J. Sherman, S. Catz, C. Calabrese, E. B. Oberg, L. Jordan, L. Grothaus, and D. Cherkin, "Adjunctive naturopathic care for type 2 diabetes: 


\section{International Journal of Science and Research (IJSR) \\ ISSN (Online): 2319-7064}

Index Copernicus Value (2013): 6.14 | Impact Factor (2014): 5.611

patient-reported and clinical outcomes after one year.," BMC Complement. Altern. Med., vol. 12, p. 44, 2012.

[17] R. Bradley, E. Kozura, H. Buckle, J. Kaltunas, S. Tais, and L. J. Standish, "Description of Clinical Risk Factor Changes During Naturopathic Care for Type 2 Diabetes," J. Altern. Complement. Med., vol. 15, no. 6, pp. 633-8, 2009.

[18] Body Mass Index - A Diagnostic Tool to Assess Obesity Praveen Kumar N V R T*, Mohanta G P, Manna P K, Manavalan R Indian J. Pharm. Pract. 2(2), Apr-Jun, 2009

[19]D. Sirbu, D. Curseu, M. Popa, and M. S. Popa, "International Conference on Advancements of Medicine and Health Care through Technology," in IFMBE Proceedings, vol. 26, 2009.

\section{Author Profile}

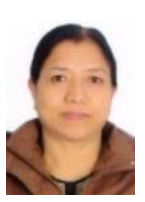

Dr. Rukamani Nair: is Medical Superintendent of Bapu Nature Cure Hospital and Yogashram, She is a Naturopathy Doctor from Osmania Univ. and Principle Investigator in the Ayush project of Type II Diabetes Mellitus.

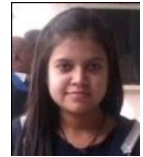

Deepali Saxena: received the B.Sc. and M.Sc. degrees in Biochemistry from Delhi University and Jamia Millia Islamia. She stayed in All India Institute for Medical Sciences (AIIMS), New Delhi to study cervix cancer. She is now working as Senior Research Fellow in the Ayush project of Type II Diabetes Mellitus with Bapu Nature Cure Hospital and Yogashram, Delhi.

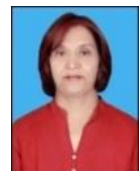

Dr. Ranjna Chawla: She is Scientist C at G. B. Pant Hospital Delhi. She is $\mathrm{PhD}$ in Bio Chemistry from PGIMER. She is the Co PI in this research team of Ayush project on type II Diabetes Mellitus.

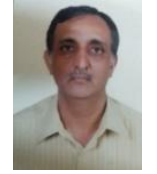

Dr. V.R Sood: He is practicing as Physician and Cardiologist in Mayur Vihar-II Delhi \& consultant at Metro Anand Hospital, Bimla Devi Hospital \& Max Balaji Hospital. He is the Co PI in the Ayush project on type II Diabetes Mellitus.

Akhil Jain received the B.Sc. and M.Sc. degrees in Statistics from Delhi University. He is working as Senior Research Fellow in ICMR, New Delhi. He is also working as part time biostatistician in Bapu Nature Cure Hospital and Yogashram, Delhi. 